\title{
RATE OF EROSION AND EXHUMATION OF CRYSTALLINE ROCKS IN THE HUNZA KARAKORAM DEFINED BY APATITE FISSION TRACK ANALYSIS
}

\author{
Dagmar KOŘíNKOVÁ ${ }^{1)}$, Martin SVOJTKA ${ }^{1)}$ and Jan KALVODA ${ }^{2) *}$ \\ ${ }^{1)}$ Institute of Geology, Academy of Sciences of the Czech Republic, Laboratory of Geological Processes, Rozvojová 269, \\ Praha 6, 165 00, Czech Republic \\ 2) Charles University in Prague, Faculty of Science, Department of Physical Geography and Geoecology, Albertov 6, Praha 2, 128 43, Czech \\ Republic \\ *Corresponding author's e-mail: kalvoda@natur.cuni.cz
}

\begin{tabular}{l} 
ARTICLE INFO \\
\hline Article history: \\
Received 28 February 2014 \\
Accepted 4 June 2014 \\
Available online 24 June 2014 \\
\hline
\end{tabular}

Keywords:

Apatite fission-track analysis

Exhumation of rocks

Erosion

Karakoram

\begin{abstract}
Rapid exhumation of rock massifs in the Hunza Karakoram has been caused by collision orogeny as well as intensive and variable climate-morphogenetic processes during the late Cenozoic. Apatite fission-track dating of crystalline rocks gave AFT-ages between $3.9 \pm 0.2 \mathrm{Ma}$ to $9.9 \pm 0.4 \mathrm{Ma}$ and constrained the period of a rapid exhumation and unroofing as Upper Miocene to Quaternary. Time-temperature curves of the samples show two trends of exhumation rate: the Upper Miocene to Pliocene period of a slow rate of ca. $0.1 \mathrm{~km} / \mathrm{Ma}$ followed by the Quaternary period of a relative rapid rate of ca. $2.6 \mathrm{~km} / \mathrm{Ma}$. The erosion rate reached up to a maximum of ca. $4000 \mathrm{~m}$ from the Upper Miocene to the present. The high intensity of recent denudation and transport of weathered and eroded material suggest their long-term influence on the exhumation of deeper parts of the rock massifs during active orogenetic processes in the Hunza Karakoram.
\end{abstract}

\section{INTRODUCTION}

Studies of the extent of denudation and erosion of near-surface parts of the Earth's crust in active orogenic belts are fundamental for knowledge of landform evolution during the late Cenozoic (e.g. Burbank, 2002). The geomorphological record of active orogeny is associated with research of climatemorphogenetic changes of landform patterns in the Karakoram (see Desio, 1974, 1979; Kalvoda, 1992a, b; Derbyshire, 1996; Seong et al., 2007, 2009; Hewitt, 2005, 2009). It provides evidence of the Quaternary evolution of the dissected high-mountain relief. In the presented study, the geomorphological signatures of extreme erosion supported by the surface uplift of the Hunza Karakoram in the late Cenozoic is compared with the thermochronological history of relevant crystalline rocks during active collision orogeny. In order to estimate the rate of exhumation of crystalline rocks from the Hunza Karakoram in north-eastern Pakistan (Fig. 1), we used the apatite fission-track (AFT) geochronology technique. Generally, this radiometric dating method provides the characteristics of the time-low-temperature evolution of studied rock masses and their cooling ages (Burbank et al., 1996) in the period from the Upper Miocene to the recent. The AFT method is also useful for studies of the denudation / exhumation orogen evolution and the tectonics-climate relationship. Our data represents new Thermochronological information from the Hunza Karakoram area and, together with already published data from the Himalaya (compare e.g. review in Thiede and Ehlers 2013), contributes to a comprehensive view of the region between the Karakoram, the Tibetan Plateau and the Himalaya affected by the convergence and collision of Indian and Eurasian plates in the period from $50 \mathrm{Ma}$ to the present.

\section{GEOLOGICAL SETTING AND LANDFORM PATTERNS OF THE HUNZA KARAKORAM}

The Karakoram Range represents a great mountain system with the highest concentration of peaks over $8000 \mathrm{~m}$ in height and one of the most heavily glaciated parts of the Earth. The Karakoram Range extends ca. $500 \mathrm{~km}$ from the easternmost extension of Afghanistan in a southeasterly direction to NE Pakistan and is part of a complex of mountain ranges at the centre of Asia (Schneider 1957, 1960; Tahirkheli, 1982; Searle, 1991), including the Hindu Kush to the west, the Pamirs to the northwest, the Kunlun Mountains to the northeast, and the Himalayas to the southeast (e.g. Desio, 1979; Rex et al., 1988). The recent orogeny of the Karakoram Range and the Himalaya are the youngest evolutionary stage of the Alpine-Himalayan system (e.g. Searle, 1991, 2007). During the Quaternary, most of these mountain ranges achieved their morphotectonic characteristics and landform patterns.

The studied area of the Hunza Karakoram includes the adjacent area lying northward of the Main Karakoram Thrust zone dividing the Karakoram from the Ladakh-Kohistan arc-batolith with the Indus 
Suture Zone on its southern margin (Fig. 1). The Indus Suture Zone is the major suture forming the boundary between the Indian plate and the Karakoram and Lhasa morphostructural blocks. It represents a small back-arc basin as a result of magmatic episodes during the Indo-Asian collision (Jurrasic and middle-Upper Cretaceous ages) before closing the Tethys Ocean at ca $50-45$ Ma (Searle, 1991). The Main Karakoram Thrust is interpreted as a steep north-dipping thrust fault zone representing a reactivated break-back thrust. It followed after the late Cretaceous closing of the Shyok suture zone (Pudsey et al., 1985; Coward et al., 1986, 1987, 1988). Karakoram high-grade metasediments were thrust southwards over low-grade metasediments previously deformed along the Shyok suture zone (Carboniferous to Albian-Aptian) and the Ladakh Batholith (Cretaceous to Eocene) (Searle et al., 1987; Searle and Tirrul, 1991). The (post)-Miocene uplift of the Karakoram was a response to the continuous crustal thickening in the above mentioned magmaticcollision periods (Rex et al., 1988; Foster et al., 1994). The young AFT-cooling ages of high-grade rocks in this thrust zone yielded ages less than $10 \mathrm{Ma}$ suggesting a late Tertiary uplift along the thrust zone.

The main morphotectonic units of the Hunza Karakoram are from SW to NE (Fig. 1):

a) Karakoram Metamorphic Complex, b) Karakoram Batholith and c) The Northern Karakoram Terrane. The Karakoram Metamorphic Complex forming the southern margin of the Karakoram consists of various metasedimentary (Hunza schists and dominantly Hunza limestone) and metaigneous granodiorite rocks, which show a complex polyphase evolution of deformation and metamorphism (Bertrand and Debon, 1986; Searle, 1986). The last stage of the evolution of the entire southern Karakoram represents low P-T metamorphism. It is related to the post-Miocene uplift along the Main Karakoram Thrust zone (Searle and Tirrul, 1991).

The Karakoram Batholith belongs, with the Ladakh- and Kohistan Batholiths and the Gandese magmatic belt, to the Trans-Himalayan plutons and gives evidence to the Late Mesozoic subduction of the Indian Plate (Coward et al., 1982; Rolland et al., 2000). The subduction of the Indian plate also documents high-pressure and/or ultra high-pressure metamorphism in the Tso Morari area and the Ladakh batholith (Sachani et al., 2004). Initial Nd, Sm and Pb isotopic compositions of the Trans-Himalayan plutons indicate that they have predominantly mantle-derived components. U-Pb zircon ages of Trans-Himalayan plutons varying from 105 to $45 \mathrm{Ma}$ (Honegger et al., 1982; Scharer et al., 1984; Weinberg and Dunlap, 2000) and their geochemistry point to the northward subduction of the Tethyan oceanic lithosphere beneath the Eurasian Plate (Singh and Jain, 2003). Along the Karakoram Batholith are widespread pre-collision granites (Hunza plutonic unit), whose geochemistry (Crawford, 1988) and age (Searle et al., 1988, 1989) suppose that they were formed in the Jurassic and
Early Cretaceous by a partial melting of the crust above a northward-dipping oceanic subduction zone along the southern continental margin of the Karakoram plate.

The Karakoram Batholith is a composite intrusion represented by two sections - the Hunza Batholith and Baltoro Granites. The Hunza Batholith is made up of a) early biotite-hornblende-bearing granodiorites with $\mathrm{U}-\mathrm{Pb}$ ages of zircons of c. $95 \mathrm{Ma}$ in the Hunza Karakoram dating the emplacement of the batholith (Le Fort et al., 1983), and b) Miocene peraluminous garnet and two-mica-bearing granites which formed a section along the Baltoro glacier (Debon et al., 1986). Granitoids of the collision zoneand also studied samples from the Hunza Karakoramindicate the presence of Paleo-Meso Proterozoic rocks, and emplacement of Early Paleozoic granitoids (Singh and Jain, 2003). The Northern Karakoram Terrane comprises sedimentary units such as Pasu limestones, Pasu slates, chiastolite slates and precollision $\mathrm{K} 2$ orthogneiss and granites.

The main localities of studied samples from the Hunza Karakoram (Fig. 1) are situated between the Hunza river and the Hispar glacier. Samples (No. 14, 18, 71, 72 and 77) were selected from an elevation profile from SW-NE transect in the Hispar and Gharesa regions of the Hunza Karakoram. Sample No. 2 is a large block of amfibolite-biotitic granite material from the Gilgit catchment area. Observations of landform patterns of peculiar relief types between the Distaghil Shar $(7886 \mathrm{~m})$ and the Hunza valley $(2000 \mathrm{~m})$ suggest extremely high rates of denudation, sediment transfer and deposition (Li Jijun et al., 1984; Kalvoda, 1990; Kalvoda and Goudie, 2007). The vertical hierarchy of variable high-mountain reliefs is striking (Derbyshire et al., 1984; Hewitt, 1989; Kalvoda, 1992a, b; Iturrizaga, 2001) from the extremely cold extraglacial ridges of the western Himalaya and the Great Karakoram Range (Fig. 2) through the heavily glaciated and periglacial areas (Fig. 3) to the seasonally cold / warm semiarid Bualtar, Nagar and Hunza valleys.

Distinctive vertical climatic zoning of the Hunza Karakoram influences various features of morphostructural and lithological control of characteristic weathering phenomena (Cílek and Kalvoda, 1983; Goudie, 1984; Goudie et al., 1984a, b; Kalvoda and Goudie 2007). There are extraordinary geomorphological hazards which include high-magnitude rapid events of mass movements triggered by earthquakes, glacier surging, avalanches, flash floods and landslides (Brunsden and Jones, 1984; Hewitt, 1989, 2009; Gardner and Hewitt, 1990; Derbyshire et al., 2001). Studies of the dynamics of glaciers are also connected with the Late Glacial and Post Glacial sedimentary record of geomorphological processes (Owen and Derbyshire, 1989, 1993; Kalvoda, 1990; Owen et al., 2002; Kuhle 2006) and very high erosion rates (more than $1 \mathrm{~cm} . \mathrm{yr}^{-1}$ ) in the Hunza Karakoram. Averaged rates of maximum incision from areal denudation for mass movements, glacial and river 


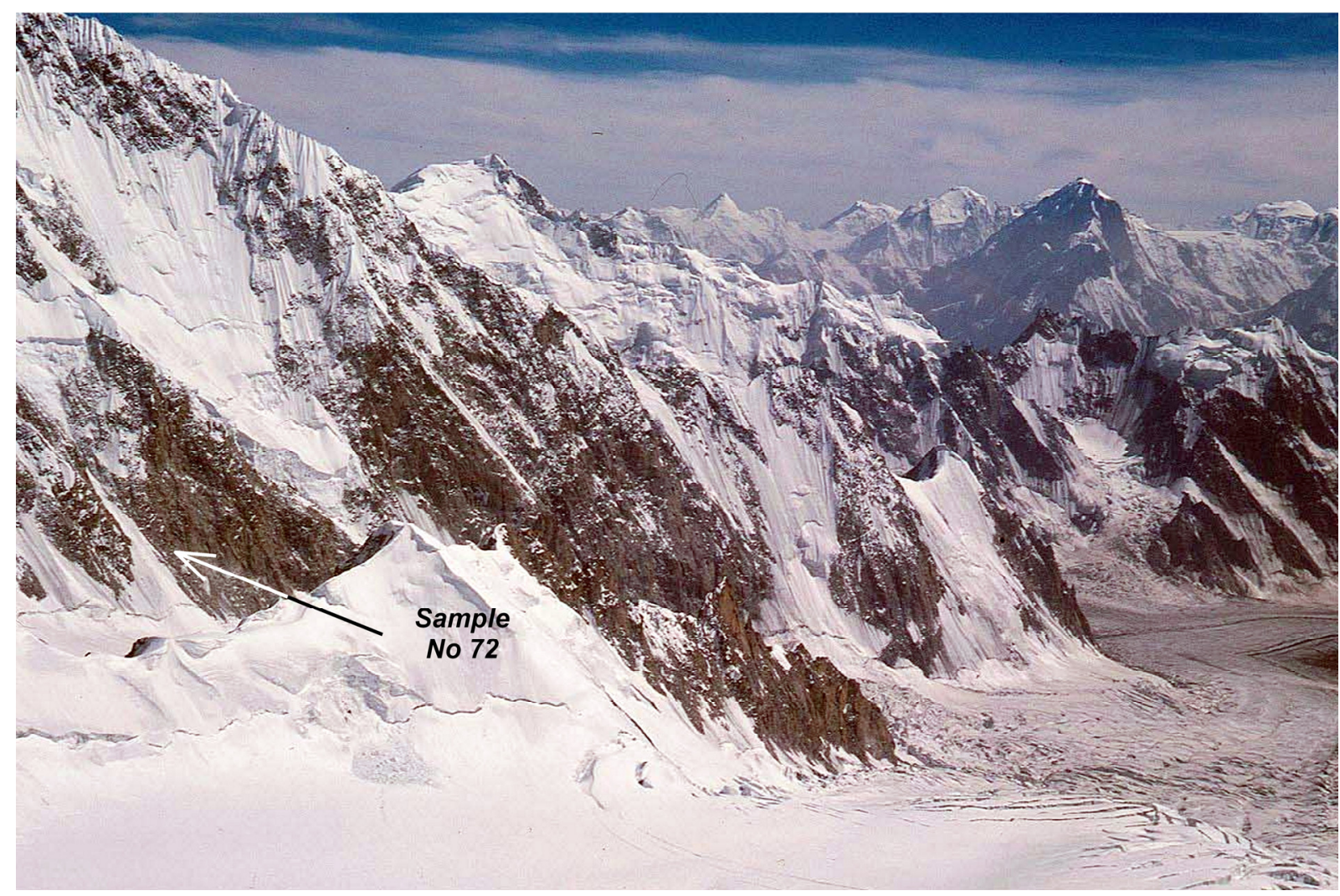

Fig. 2 The western catchment area of the glaciers of the Trivor Massif $(7720 \mathrm{~m})$ is divided into zones of hanging and slope glaciers at the granodiorite crests and their cliffs (see arrow for location of the sample No. 72) and relatively broad cirque floors completely filled with ice and snow masses. Photo by Jan Kalvoda.

erosion for the past ca $55 \mathrm{ka}$ are recorded between 2.2 and $1.1 \mathrm{~cm}^{-y^{-1}}$ (Goudie et al., 1984a; Derbyshire, 1996; Kalvoda and Goudie 2007). Similarly as in neighbouring regions (compare e.g. Kuhle, 1988a, b, 2001, 2006; Iturrizaga, 2001; Kalvoda et al., 2004; Hewitt, 2005, 2009, Seong et al., 2007, 2009; Hewitt et al., 2011), a striking phenomenon of the Hunza Karakoram is that the oldest relics of Quaternary sediments, which are preserved in accumulation landforms of mountainous valleys and basins, are younger than $2 \times 10^{5}$ years but most of them are from the Upper Pleistocene and younger than ca $50 \times 10^{3}$ years.

\section{METHODS AND ROCK SAMPLES \\ 3.1. ANALYTICAL TECHNIQUES}

Apatite Fission Track analysis (AFTA) was used in order to understand the time-low-temperature evolution of crystalline rocks from studied area. This dating method is based on radiation damage trails ("fission tracks") within apatite grains produced continuously during geological time by spontaneous fission of single atoms of ${ }^{238} \mathrm{U}$. For details and principle of the analysis see e.g. papers by Fleischer et al. (1965), Naeser (1979), Wagner and Van den Haute (1992), Gallagher et al. (1998), Jonckheere and Van den Haute (2002), Ketcham (2005) and Ketcham et al. (2007a). Fission-track ages and exhumation rates of studied samples are identified by measuring the concentration of uranium in apatite grains. It is determined by irradiation of the samples in a nuclear reactor with thermal neutrons. These neutrons induce fission of ${ }^{235} \mathrm{U}$ isotopes in the irradiated sample. The induced fission-track density $\left(\rho_{\mathrm{i}}\right.$; number of tracks $/ \mathrm{cm}^{2}$ ) is obtained in an identical way as spontaneous tracks (by etching and counting tracks using an optical microscope) and provides a measure for the ${ }^{235} \mathrm{U}$ concentration. Because in nature the ${ }^{235} \mathrm{U} /{ }^{238} \mathrm{U}$ ratio is a constant, the overall uranium concentration can be derived and finally should enable the age of the studied samples to be calculated.

Time-temperature evolution of the studied samples is defined by a combination of confined (horizontal) track length measurements and determination of the fission track-age of individual apatite grains. Fission tracks (FT) are thermally unstable and each individual decay event can be identified. The maximum length of the apatite FT $(16.3 \mu \mathrm{m})$ is shortening (annealing) at a rate which depends on the temperature at the time of their forming. The final shortening is reflected by thermal annealing determined by the highest temperature which the track has experienced.

The apatite grains of studied samples were processed using conventional separation methods: crushing, Wilfley table-density separation, magnetic and heavy liquid techniques to obtain the purest apatite fractions. The subsequent analytical techniques 


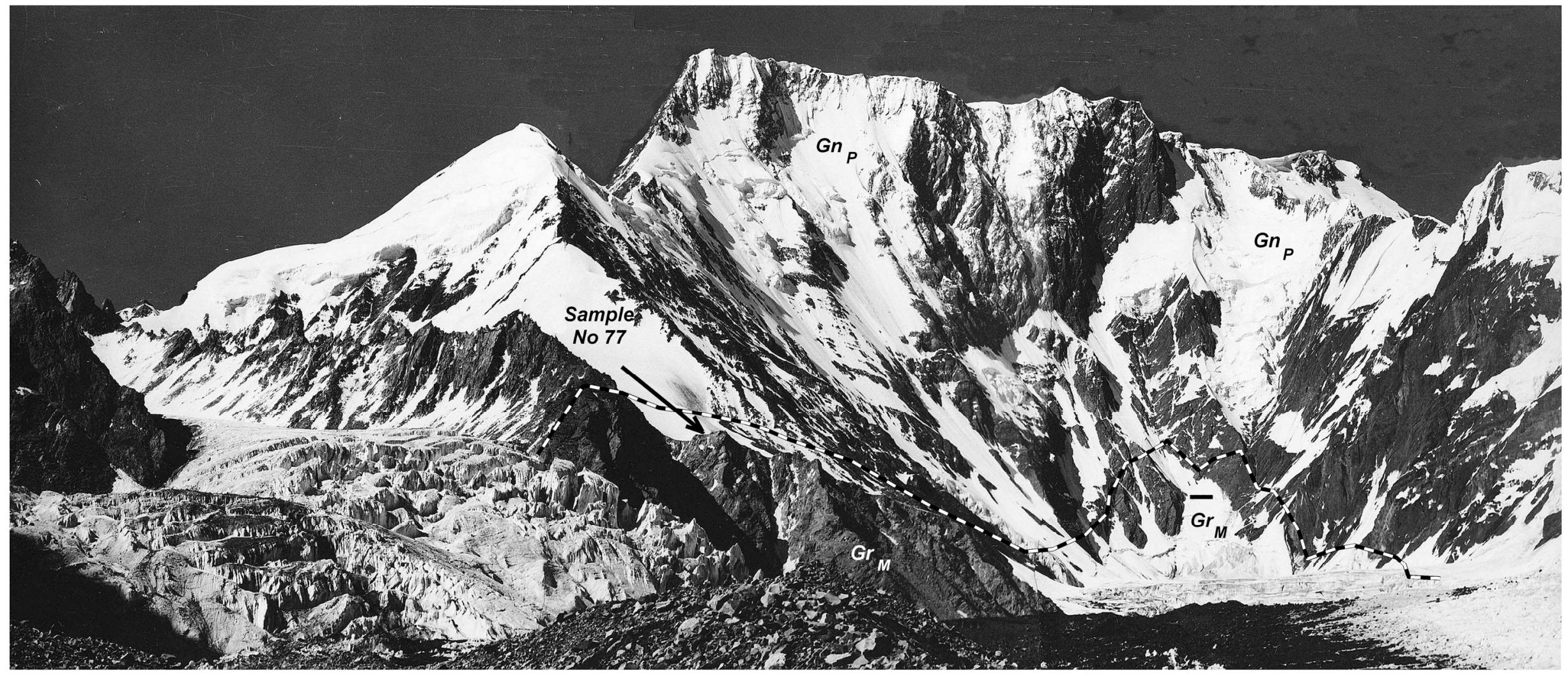

Fig. 3 The more than $2000 \mathrm{~m}$ high south-eastern face of the Lupar Shar Massif (7 $220 \mathrm{~m})$, with a series of hanging glaciers feeding the large valley glacier, is built of Miocene amfibol-biotitic granodiorites $\left(\mathrm{Gr}_{\mathrm{M}}\right.$, see arrow for location of the sample No. 77 , biotitic quartz diorite) and Palaeozoic black gneisses ( $\left.\mathrm{Gn}_{\mathrm{P}}\right)$ of the Great Karakoram Range. Photo by Jan Kalvoda. 
Table 1 Apatite fission-track analytical data of the studied rock samples from the Hunza Karakoram. Key: $\rho_{\mathrm{s}}-$ spontaneous track density of a sample; $\mathrm{N}_{\mathrm{s}}-$ number of tracks counted to determine $\rho_{\mathrm{s}} ; \rho_{\mathrm{i}}$ - induced track density of a sample measured in a muscovite external detector; $\mathrm{N}_{\mathrm{i}}-$ number of tracks counted to determine $\rho_{\mathrm{i}} ; \rho_{\mathrm{d}}$ - induced track density of glass dosimeter CN5 measured in a muscovite external detector; $\mathrm{N}_{\mathrm{d}}-$ number of tracks counted to determine $\rho_{\mathrm{d}}$; AFT-age - apatite fission-track age with its $1 \sigma$ error; $\mathrm{n}$ - number of counted grains; $\mathrm{P}\left(\chi^{2}\right)$ - probability of obtaining the observed value of $\chi^{2}$ parameter, for $\mathrm{N}$ degree of freedom, where $\mathrm{N}=$ (number of counted crystals) - 1 (Galbraith, 1981; Green, 1981; Green et al., 1989); L - mean length of horizontal confined fission tracks with 1 standard error (S.E.) in all crystallographic orientations; $\mathrm{N}$ - number of measured tracks to determine $\mathrm{L} ; \sigma-$ standard deviation for the length-distribution of confined fission tracks.

\begin{tabular}{|c|c|c|c|c|c|c|c|c|c|c|c|}
\hline $\begin{array}{c}\text { № of } \\
\text { sample }\end{array}$ & Locality & $\begin{array}{c}\text { Elevation } \\
{[\mathrm{m}]}\end{array}$ & $\begin{array}{l}\rho_{\mathbf{s}}\left(\mathbf{N}_{\mathrm{s}}\right) \\
{\left[\mathrm{x} 10^{6}\right.} \\
\left.\mathrm{cm}^{-2}\right]\end{array}$ & $\begin{array}{l}\rho_{\mathbf{i}}\left(\mathbf{N}_{\mathrm{i}}\right) \\
{\left[\mathrm{x} 10^{6}\right.} \\
\left.\mathrm{cm}^{-2}\right]\end{array}$ & $\begin{array}{c}\rho_{\mathbf{d}}\left(\mathbf{N}_{\mathrm{d}}\right) \\
{\left[\mathrm{x} 10^{6}\right.} \\
\left.\mathrm{cm}^{-2}\right]\end{array}$ & n & $\begin{array}{l}\text { AFT- } \\
\text { age } \\
{[\mathrm{Ma}} \\
\pm 1 \sigma]\end{array}$ & $\begin{array}{c}\mathbf{P}\left(\chi^{2}\right) \\
{[\%]}\end{array}$ & $\begin{array}{l}\mathbf{L}(\mathbf{N}) \\
{[\mu \mathrm{m}]}\end{array}$ & $\begin{array}{c}\boldsymbol{\sigma} \\
{[\mu \mathrm{m}]}\end{array}$ & $\begin{array}{c}\text { Cl- } \\
\text { content } \\
{\left[\mathrm{wt}^{0} \%\right]}\end{array}$ \\
\hline 2 & $\begin{array}{l}2 \mathrm{~km} \mathrm{~W} \\
\text { from the } \\
\text { confluence } \\
\text { of the } \\
\text { Hunza and } \\
\text { Gilgit } \\
\text { rivers }\end{array}$ & 2200 & $\begin{array}{c}2.357 \\
(1702)\end{array}$ & $\begin{array}{c}8.536 \\
(6163)\end{array}$ & $\begin{array}{c}3.21 \\
(6021)\end{array}$ & 70 & $\begin{array}{c}9.9 \pm \\
2.4\end{array}$ & $<1$ & $\begin{array}{c}10.3 \pm \\
2.8 \\
(155)\end{array}$ & 0.2 & 0.025 \\
\hline 14 & $\begin{array}{l}2 \mathrm{~km} \mathrm{~W} \\
\text { from town } \\
\text { Aliabad }\end{array}$ & 2400 & $\begin{array}{c}0.192 \\
(1385)\end{array}$ & $\begin{array}{c}1.437 \\
(10375)\end{array}$ & $\begin{array}{c}3.16 \\
(5985)\end{array}$ & 70 & $\begin{array}{c}5.3 \pm \\
1.3\end{array}$ & $<1$ & $\begin{array}{c}11.7 \pm \\
2.3 \\
(108)\end{array}$ & 0.2 & 0.015 \\
\hline 18 & $\begin{array}{c}\text { Rocky } \\
\text { slopes N } \\
\text { of Nagar } \\
\text { village }\end{array}$ & 2550 & $\begin{array}{c}0.204 \\
(1474)\end{array}$ & $\begin{array}{c}1.414 \\
(10226)\end{array}$ & $\begin{array}{c}3.16 \\
(5985)\end{array}$ & 67 & $\begin{array}{c}6.3 \pm \\
1.3\end{array}$ & $<1$ & $\begin{array}{c}10.7 \pm \\
2.4 \\
(147)\end{array}$ & 0.2 & 0.016 \\
\hline 77 & $\begin{array}{c}\text { Nunatac } \\
\text { near S-wall } \\
\text { of the } \\
\text { Lupar Shar }\end{array}$ & 5200 & $\begin{array}{c}0.172 \\
(1340)\end{array}$ & $\begin{array}{c}1.616 \\
(12600)\end{array}$ & $\begin{array}{c}3.93 \\
(6003)\end{array}$ & 66 & $\begin{array}{c}7.5 \\
\pm 1.8\end{array}$ & $<1$ & $\begin{array}{c}11.2 \pm \\
2.6 \\
(162)\end{array}$ & 0.2 & 0.012 \\
\hline 72 & $\begin{array}{l}\text { Rock-wall } \\
\text { of the } \\
\text { cirque of } \\
\text { Gharesa } \\
\text { glacier }\end{array}$ & 5500 & $\begin{array}{c}0.211 \\
(1439)\end{array}$ & $\begin{array}{c}2.158 \\
(14724)\end{array}$ & $\begin{array}{c}3.16 \\
(5985)\end{array}$ & 58 & $\begin{array}{c}3.9 \pm \\
0.8\end{array}$ & $<1$ & $\begin{array}{c}11.1 \pm \\
2.3 \\
(178)\end{array}$ & 0.2 & 0.035 \\
\hline 71 & $\begin{array}{c}\text { S-wall of } \\
\text { the Trivor } \\
\text { Massif }\end{array}$ & 5650 & $\begin{array}{c}0.167 \\
(1514)\end{array}$ & $\begin{array}{c}1.626 \\
(14719)\end{array}$ & $\begin{array}{c}3.16 \\
(5985)\end{array}$ & 70 & $\begin{array}{c}4.1 \pm \\
0.9\end{array}$ & $<1$ & $\begin{array}{c}12.1 \pm \\
2.2 \\
(167) \\
\end{array}$ & 0.2 & 0.024 \\
\hline
\end{tabular}

for dating of apatites in the presented study are identical to the instructions described by Fitzgerald and Gleadow $(1988,1990)$ and Foster and Gleadow (1992). The apatite crystals were sealed in epoxy resin, polished, etched with a $2.5 \% \mathrm{HNO}_{3}$ solution for $70 \mathrm{~s}$ at $22{ }^{\circ} \mathrm{C}$ to enable visibility of the spontaneous fission tracks, fitted with a muscovite external detector (Miller et al., 1993) and irradiated in a nuclear reactor (Oregon State University Radiation Center) by thermal neutrons. For details of specific laboratory instrumentation and fission track procedure at the Institute of Geology, Academy of Sciences of the Czech Republic, see Murakami and Svojtka (2007). The Zeta calibration factor, determined in accordance with Hurford and Green (1983), together with the measured FT-densities, was used in the equation for the FT-ages calculation in the Trackscan software. Using TrackKey $4.2 \mathrm{~g}$ software (Dunkl,
2002), the FT-ages of the studied samples were graphically dispayed and evaluated. Confined (horizontal) tracks were measured as 'tracks in tracks' type in $\mathrm{c}$ axis parallel etched and polished surfaces of apatite grains and were normalized for a crystallographic angle using a c-axis projection (Green and Durrani, 1977; Ketcham et al., 2007a). In addition to temperature mentioned above, the amount of chlorine in the apatite lattice represents a critical compositional control on the degree of annealing. Chlorine-rich apatites are more resistant (slowly annealed) to track annealing than fluorine-rich apatites (e.g. Barbarand et al., 2002). Accordingly, Cl-content was measured by electron probe microanalyzer. As a result, all the studied apatites are fluorine-apatites (Cl-content was below $0.05 \mathrm{wt} \%$, see Table 1). Such low chlorine content in apatites does not influence annealing parameters. In time-temperature modelling 


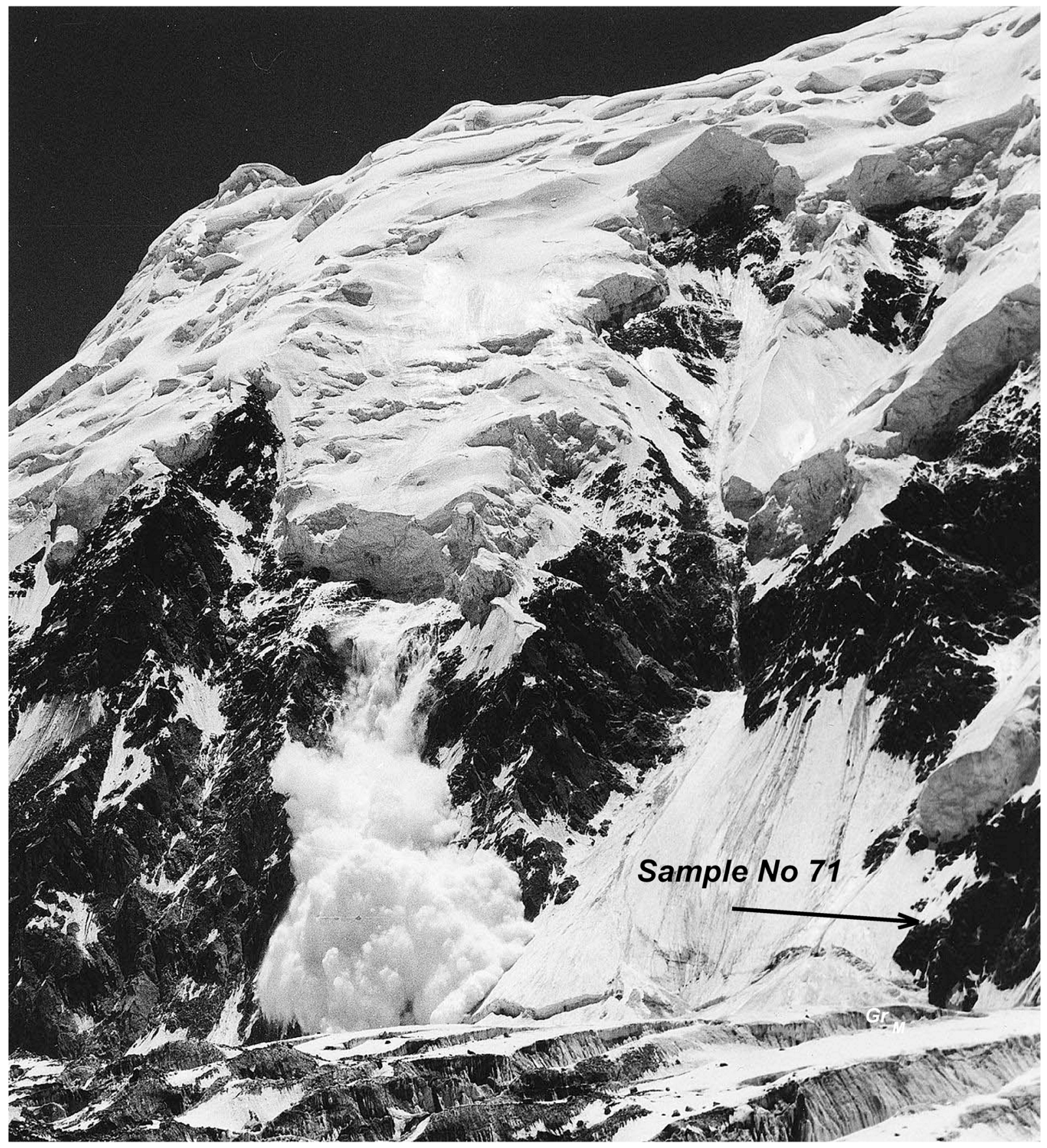

Fig. 4 Conspicuous detachment area of snow- and ice avalanches from granodiorite rock-slopes (see arrow for location of the sample No. 71) south of the Distaghil Shar (7 $885 \mathrm{~m})$ demonstrate the high efficiency of climate-morphogenetic processes and rapid geomorphic hazards in the Karakoram. Photo by Jan Kalvoda

graphs (Fig. 6) are marked by "black boxes" geological constraints that represent independent geochronological information from previously published papers. Using time-temperature information on rocks with similar tectonometamorphic history as studied rocks (see legend in Fig. 6), but with different isotope system and different blocking temperature, significantly improves the $\mathrm{t}-\mathrm{T}$ modelling to higher temperatures.

\subsection{GEOMORPHOLOGICAL POSITIONS OF THE STUDIED ROCK SAMPLES}

For the purposes of AFT analysis a set of varied crystalline rock samples from the Hunza Karakoram was used. The samples come mainly from the SW-NE transect in the Hispar and Gharesa regions of the Hunza Karakoram (Fig. 1). The highest mountain massifs from these regions of the central Karakoram are Distaghil Shar $(7885 \mathrm{~m})$, Trivor $(7720 \mathrm{~m})$ and Lupar Shar (7 $220 \mathrm{~m})$. The glaciated high-mountain zone displays an integration of deep weathering of rocks with major glacial and nival processes (Fig. 3). 


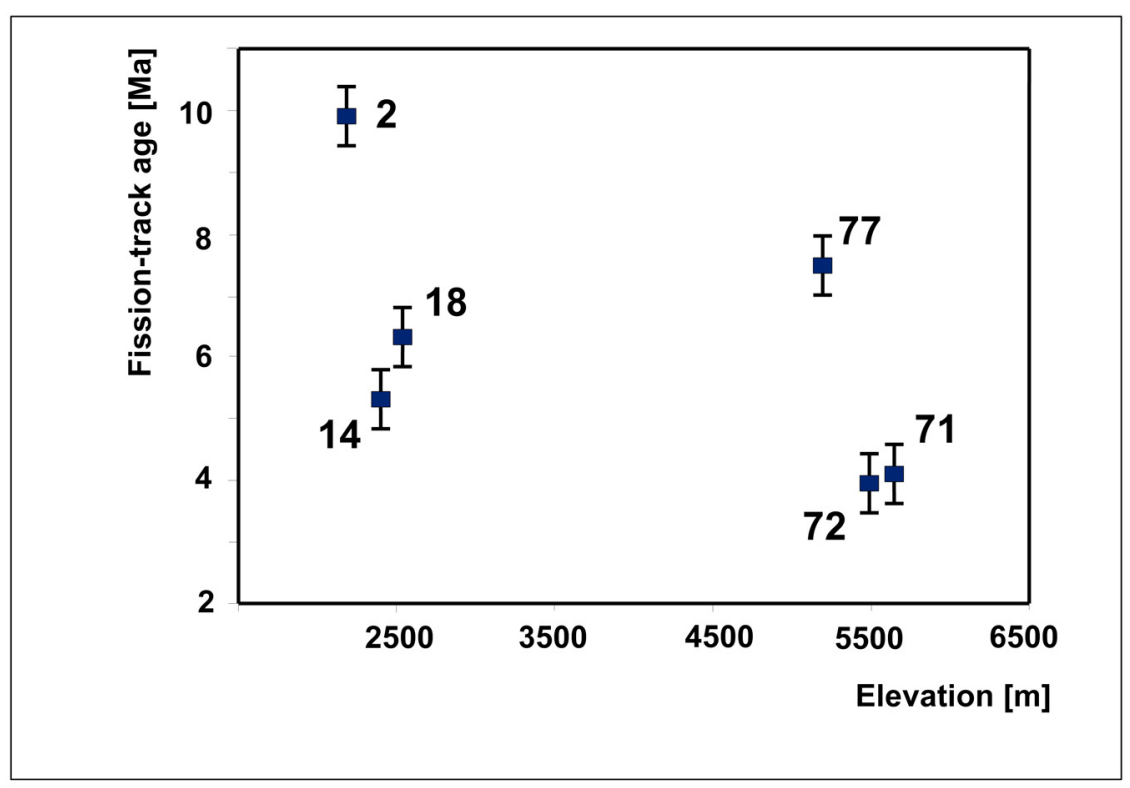

Fig. 5 Relation between apatite fission-track age and topographical elevation of the studied rock samples in the Hunza Karakoram.

The valleys and ridges of the Hispar Karakoram are overfilled by glacier masses at high altitudes above $5600 \mathrm{~m}$ a. s. 1. Large ice source areas contrast with the very narrow canyon-like lower parts of the valleys (Fig. 4). The recent retreat of the glaciers is accompanied by an increase of the active periglacial processes which is a dominant phenomenon of the present-day changes of landform patterns stimulated by climate-morphogenetic processes.

Variable lithological types of crystalline rocks were collected from altitude of ca. 2400 to $5600 \mathrm{~m}$ a.s.l. Sampling strategy (Fig. 1) was carried out with the aim to cover both crystalline units (Karakoram Metamorphic Complex and Karakoram Batholith) that are located in uneasily accessible terrain. Sample collection represents selection of representative lithological rock-types suitable for AFT dating and not continuous altitude profile. Exception is sample No. 2 that was collected from a large block $\left(30 \mathrm{~m}^{3}\right)$ of amfibolite-biotitic granite from flood accumulation on the right bank of the Gilgit river $(2200 \mathrm{~m}), 2 \mathrm{~km}$ westward from the confluence of the Hunza and Gilgit rivers (Fig. 1). It was transported from the middle part of the Gilgit catchment area situated SW of the Hunza region of the Karakoram. Other samples were collected from rock outcrops and represent "in situ" material. Sample No. 14 is calcalcalic-biotitic granite with amfibole from a large rock outcrop near the foot of a structural slope (2 $400 \mathrm{~m}), 2 \mathrm{~km}$ westward from the small town Aliabad in the Hunza valley. Sample No. 18 is amfibole-biotitic granodiorite from a rock outcrop northward from Nagar village $(2550 \mathrm{~m})$ in the middle part of a steep erosional slope of the Hispar valley. Sample No. 71 is muscovite-biotitic granodiorite from $5650 \mathrm{~m}$ (Fig. 4) in the southern wall of the Trivor Massif. Sample No. 72 is biotitic granodiorite from a large rock wall of a cirque of the
Gharesa glacier (5 500 m, Fig. 2) in the Trivor Massif. Sample No. 77 is biotitic quartz diorite from strongly cryogenically weathered nunatac (5 $200 \mathrm{~m}$, Fig. 3) near the southern wall of the Lupar Shar.

Terms such as denudation, exhumation and erosion used in this paper correspond to (re)definition by England and Molnar (1990) and further description by Summerfield (1991) and Ring et al. (1999). Denudation is understood as a removing (unroofing) of material from an area on the Earth's surface, exhumation characterizes unroofing of a point or vertical transect of studied rocks. Denudation and exhumation occur as a result of erosion and tectonic processes (e.g. Lisker et al., 2009). Erosion is a set of geomorphic processes causing weathering and the transport of material. The rate of erosion quantifies the transported material from one place on the Earth's surface to another. Active tectonics involves processes such as extension, normal faulting and thrusting that result in rapid removing of large rock volumes. The rate of denudation and exhumation of rocks express results of integrated activity of climate-morphogenetic and tectonic processes.

\section{RESULTS}

Apatite fission-track dating of the "in situ" rocksamples from the Hunza Karakoram yielded ages between $3.9 \pm 0.8 \mathrm{Ma}$ to $7.5 \pm 1.8 \mathrm{Ma}$ in narrow age cluster (Table 1). AFT- age of flood-transported sample No. 2 yielded $9.9 \pm 2.4 \mathrm{Ma}$, which is comparable with observed older cluster of ages and probably reflect influence of higher altitude of the source area. There is no clear correlation between apatite fission-track age and topographic elevation (m a. s. 1.) of the studied samples (Fig. 5). All the studied samples failed the probability test $\mathrm{P}\left(\chi^{2}\right)$ for Poisson distribution because $\mathrm{P}$-values are $<1 \%$. The samples 
have experienced a long-term cooling period within the apatite partial annealing zone. The age spread of all apatite grains show relatively distinct homogenous age-population in the radial plots (Figs. 6 and 7). It also is documented by minimal differences in the chlorine content (Table 1) between individual apatite grains within the samples.

The apatite grains of samples were examined by electron microprobe analyser (Cameca SX 100) for chlorine content, which varies between 0.012 to $0.035 \mathrm{wt} \%$ and thus represents fluorapatites. All studied apatites from the Hunza Karakoram provided a large number of confined tracks (above 100 tracks) necessary for track-length measurement and consequently for time-temperature modelling (Figs. 6 and 7). Measured track-lengths for the "in situ" rocksamples vary from $10.7 \pm 2.4 \mu \mathrm{m}$ to $12.1 \pm 2.2 \mu \mathrm{m}$, and have been shortened on average $4.9 \pm 2.4 \mu \mathrm{m}$ from maximal value. The average track-length of the flood-transported sample No. 2 was $10.3 \pm 2.8 \mu \mathrm{m}$ (Table 1) and is shorter than the maximal value by about $6 \pm 2.8 \mu \mathrm{m}$. The maximal peak in the tracklength-frequency diagrams (Fig. 7C) shows a longterm stable uplift across the apatite partial annealing zone of all the studied samples, which also confirm the modelled time-temperature trajectories in Figure 6. Sample No. 2 had this uplift probably more gradually than the other "in situ" samples. Figure 8 captures a striking correlation between fission-track length and elevation of collected samples. The red line in the graph shows a slightly increasing trend in average lengths of measured confined tracks with increasing elevation of the studied samples. The observed trend can be interpreted as a signature of increasing morphogenetic impact of erosion rates stimulated by the large-scale tectonic uplifts of the Karakoram region.

Time-temperature modelling of all the studied samples shows a similar thermal history style, involving a period of total thermal annealing and a subsequent period of cooling corresponding to considerable exhumation and erosion processes. Based on time-temperature curves and track-lengthdistribution histograms (Figs. 6 and 7), apatite fissiontrack ages can be interpreted as cooling ages accompanying denudation of the Hunza Karakoram in the late Cenozoic. Time-temperature (t-T) curves of samples (Fig. 6) testify to two dominant trends of cooling rate in both above units (Karakoram Metamorphic Complex and Karakoram Batholith): an Upper Miocene to Pliocene period of a slow cooling rate of ca. $0.1 \mathrm{~km} / \mathrm{Ma}$ followed by the Quartenary period of a relatively rapid cooling rate of ca. $2.6 \mathrm{~km} / \mathrm{Ma}$. Despote slightly different trajectory in individual samples, the average cooling rates are similar to all studied samples. Differences in t-T trajectory are mainly for uplift of samples from Oligocene to Miocene, the later stages are comparable (Fig. 6). The later period of cooling is associated with the approach of (sampled) rock assemblages near late
Cenozoic denudation and/or erosion surfaces. However, time-temperature curve of the one transported sample No. 2 is well comparable with "in situ" samples No. 18 and 77. These samples have endured a prolonged period of cooling within the apatite partial annealing zone (APAZ) and its uplift was probably more gradually than the other samples.

Apatite fission-track $\mathrm{t}-\mathrm{T}$ data indicate that the studied rock samples from the Hunza Karakoram were positioned in shallow sub-surface depths up to $4000 \mathrm{~m}$ from the Oligocene-Miocene boundary for samples No. 2, 18 and 77 and from the Upper Miocene for samples No. 14, 71 and 72. Denudation and erosion of rock masses in the Hunza Karakoram estimated by a combination of current elevations of samples and depths of the fossil apatite partial annealing zone reached up to $4000 \mathrm{~m}$ from the Upper Miocene to the present. In view of the present-day elevation of individual samples, it is possible to determine the maximum rock uplift (Table 2), which can be assessed as more than $9000 \mathrm{~m}$.

Table 2 Maximum denudation, rock uplift and surface uplift of the studied samples from the Hunza Karakoram. Key: D - maximum denudation (exhumation and erosion) from Upper Miocene to Recent [m]; $\mathrm{U}_{\mathrm{S}}$ - surface uplift of studied samples [m], which reflects changes in surface elevation and responds to present elevation of them; $\mathrm{U}_{\mathrm{R}}-$ rock uplift $=$ $\mathrm{U}_{\mathrm{S}}+\mathrm{D}[\mathrm{m}]$.

\begin{tabular}{clll}
\hline $\begin{array}{l}\text { No of } \\
\text { sample }\end{array}$ & $\mathbf{D}[\mathrm{m}]$ & $\mathbf{U}_{\mathbf{S}}[\mathrm{m}]$ & $\mathbf{U}_{\mathbf{R}}[\mathrm{m}]$ \\
\hline 2 & $\leq 4000$ & 2200 & $\leq 6200$ \\
14 & $\leq 4000$ & 2400 & $\leq 6400$ \\
18 & $\leq 4000$ & 2550 & $\leq 6550$ \\
77 & $\leq 4000$ & 5200 & $\leq 9200$ \\
72 & $\leq 4000$ & 5500 & $\leq 9500$ \\
71 & $\leq 4000$ & 5650 & $\leq 9650$ \\
\hline
\end{tabular}

\section{DISCUSSION}

Pioneer geological and geographical studies have already argued that continuous denudation of the nearsurface part of Hunza Karakoram rock massifs from the Neogene to the present time is caused by active orogeny as well as intensive exogenous processes (compare Paffen et al., 1956; Schneider 1957, 1960; Wiche, 1959, 1962; Desio, 1974, 1979; Desio and Martina 1972). Thermochronological data confirmed very effective denudation, erosion and transport of near-surface rock masses during the late Cenozoic. Rapid exhumation (unroofing) of deeper parts of the rock massifs also needs vigorous transport agencies. Apatite fission-track dating of variable lithological types of crystalline rocks from the Karakoram Metamorphic Complex and the Karakoram Batholith gives evidence of an increasing significance of erosion 
rates from the period of a slow rate (Upper Miocene to Pliocene) to the Quaternary period of a relative rapid rate. The high intensity of recent denudation and rapid transport of weathered and eroded material correlates with a striking absence of older Quaternary sediments (e.g. Kalvoda, 1984; Hewitt, 1989, 2009, Hewitt et al., 2011; Kalvoda and Rosenfeld, 1998; Goudie and Kalvoda, 2004). It suggests a long-term influence of these morphogenetic processes on the exhumation of deeper parts of the Earth's crust during the active collision orogeny of the Hunza Karakoram.

In strikingly uplifted orogenic belts, an increase of fission-track age with increasing elevation is often observed. Such a linear data set implies uplift of the area as a homogeneous block without significant faulting structures. In opposite, blocks without a clear correlation between age and elevation represent areas strongly affected by faulting (Wagner et al., 1977; Naeser, 1979). Due to the observed uncertain ageelevation correlation from the studied area (Fig. 5), we assume that the measured apatite fission-track ages from the Hunza Karakoram were probably affected by thrusting and faulting in an active orogenic belt, and uplifted as a more independent rock-massive blocks. A similar non-linear data set is described from Gasherbrum IV diorite by Cerveny et al. (1989) and interpreted as variable time-spatial tectonic activity along thrust- and fault-systems. Further reason can be suggested according to Le Fort et al. (1983) as a partial resetting of fission-track ages by contact metamorphism during emplacement of the Hunza Batholith (106 - $95 \mathrm{Ma}$, U-Pb zircon age) and also by subsequent Eocene regional metamorphism at the time of the Indo-Eurasian collision. Moreover, hydrothermal fluids migrated through fractures are mentioned by Cerveny et al. (1989) as a resetting factor for annealing of fission-track data from the Hunza and Gasherbrum regions. The differences in the measured apatite fission-track ages can probably be caused by extreme dissection of high-mountain relief, which affects erosion rates.

Early Cretaceous zircon fission-track ages of K2gneisses $(120-115 \mathrm{Ma})$ in the Gasherbrum IV region can be correlated with Karakoram Batholith Granitoids (106 Ma) and with the Hunza Batholith (106 Ma) including early to pre-Miocene components (Cerveny et al., 1989). Both regions lie close to the Karakoram Thrust Zone and, therefore, they probably experienced similar tectonic evolution. We adopted the value of $30{ }^{\circ} \mathrm{C} / \mathrm{km}$ as geothermal gradient, typical for orogenic belts for T-t modelling. Similar values of palaeogeothermal gradient were used in late Tertiary rocks of the northern Karakoram by Cerveny et al. (1989). Using this value, calculation of the amount of erosion material is considered to be about $4 \mathrm{~km}$ from Upper Miocene till recent. All studied F-rich apatites had a chlorine content of below $0.4 \mathrm{wt} \%$, which is the threshold for no effect on the annealing parameters in apatite grains (Barbarand et. al., 2003). According to the very close Cl-values spread, it seems that the studied samples probably represent uniform age population. Track-length frequency histograms (Fig. 7) demonstrate a slightly bimodal distribution of confined tracks in apatite grains. This distribution illustrates cooling evolution associated with the maximally two thermal events for the studied rocks. This also corresponds to the radial plots (Fig. 7), which did not reveal more clearly defined agepopulation of apatite grains in most of the samples.

Foster et al. (1994) studied apatite separated from samples collected from elevations of 5300 to $8611 \mathrm{~m}$ in the K2 region of the Baltoro glacier. The apatite yielded fission-track ages of $2.1 \pm 0.6$ to $4.3 \pm$ 1.4 Ma, and suggest an initial, apparent denudation rate of 3-6 mm. $\mathrm{yr}^{-1}$ commencing after $5 \mathrm{Ma}$. Shroder and Bishop (2000) thought that rapid erosional unroofing of the Nanga Parbat Massif in the western Himalaya was initiated at $12-10 \mathrm{Ma}$. It also can be mentioned that even rough valuations of erosion and denudation rates suggested in pioneer papers about the Karakoram (e.g. Schneider, 1957; Desio, 1974; Goudie et al., 1984b) approximately coincide with recent analytic and modelling studies.

Data in our paper correspond well with published data from mineral cooling ages summarized by Thiede and Ehlers (2013) for the northern Greater Himalaya, adjacent to the Karakoram. These authors provide evidence that measured low denudation rates were $<1 \mathrm{~mm} / \mathrm{yr}$ in the period $10-4 \mathrm{Ma}$ followed by rapid faster rates of $1.2-2.6 \mathrm{~mm} / \mathrm{yr}$ in the last cca. $4 \mathrm{Ma}$. It confirms our AFT results for the Hunza Karakoram, when we distinguish two stages of cooling: an Upper Miocene to Pliocene period of a slow cooling rate (ca. $0.1 \mathrm{~mm} / \mathrm{yr}$ ) followed by the Quaternary period of a relatively rapid cooling rate (ca. $2.6 \mathrm{~mm} / \mathrm{yr}$ ). Variability in denudation rates across the Himalaya as referred to in Thiede and Ehlers (2013) are observed as temporal and spatial differences: in a ca $1000 \mathrm{~km}$ long belt of the southern Greater Himalaya denudation rates were higher (cca. $1.5-3 \mathrm{~mm} / \mathrm{yr}$ ) between $10-2 \mathrm{Ma}$ followed by lower rates of ca. $0.5-2.6 \mathrm{~mm} / \mathrm{yr}$ in the last $2 \mathrm{Ma}$.

\section{CONCLUSIONS}

Low-temperature stage of the Hunza Karakoram crystalline rocks from Karakoram Metamorphic Complex and Karakoram Batholit gives evidence about exhumation processes during active collision orogeny. AFT-ages of studied rocks yielded between $3.9 \pm 0.2 \mathrm{Ma}$ to $9.7 \pm 0.4 \mathrm{Ma}$ and constrained the period of a rapid exhumation and unroofing as Upper Miocene to Quaternary. Time-temperature (t-T) curves of all the samples show two dominant trends of exhumation rate: the Upper Miocene to Pliocene period of a slow rate of ca. $0.1 \mathrm{~km} / \mathrm{Ma}$ followed by the Quaternary period of a relatively rapid rate of ca. $2.6 \mathrm{~km} / \mathrm{Ma}$. Track-length distributions and modelled $\mathrm{t}-\mathrm{T}$ curves defined AFT-ages of crystalline rocks as cooling ages accompanying the late Cenozoic denudation and uplift in Hunza Karakoram. This t-T 
evolution and uplift of rocks across the apatite total annealing zone to the current temperature on present erosion surface documents a very active orogenic belt. The erosion rate reached up to a maximum of cca. $4000 \mathrm{~m}$ from Upper Miocene to the present. The maximum (topographical) uplift of studied rocks can be estimated as more than $9000 \mathrm{~m}$. Rapid exhumation of crystalline rocks in the Hunza Karakoram has been caused by collision orogeny as well as intensive and variable climate-morphogenetic processes during the late Cenozoic. The high intensity of denudation and transport of eroded material suggest their long-term influence on the exhumation of deeper parts of the rock massifs during orogenetic processes in the Karakoram.

\section{ACKNOWLEDGEMENTS}

The paper was completed in the framework of projects PRVOUK P43 "Geography" of the Faculty of Science, Charles University in Prague and AVOZ30130516 of the Academy of Sciences of the Czech Republic.

\section{REFERENCES}

Barbarand, J., Hurtford, T. and Carter, A.: 2003, Variation in apatite fission-track length measurement: implications for thermal history modelling. Chemical Geology, 198, No. 1-2, 77-106. DOI: 10.1016/S0009-2541(02)00423-0

Bertrand, J.M. and Debon, F.: 1986, Evolution tectonique polyphase de la chaine du Karakoram (Baltoro, Nord Pakistan). Comptes Rendu des séances de I'Academie des Sciences, 303, 1611-1614.

Brunsden, D. and Jones, D.K.C.: 1984, The geomorphology of high magnitude - low frequency events in the Karakoram mountains. In: Miller, K.J. (Ed.): The International Karakoram Project. Cambridge University Press, Cambridge, 1, 343-388.

Burbank, D.W.: 2002, Rates of erosion and their implications for exhumation. Mineralogical Magazine, 66, No. 1, 25-52. DOI: 10.1180/0026461026610014

Burbank, D.W., Leland, J., Fielding, E., Anderson, R.S., Brozovic, N., Reid, M.R. and Duncan, C.: 1996, Bedrock incision, rock uplift and threshold hillslopes in the Northwestern Himalayas. Nature, 379 (6565), 505-510. DOI: $10.1038 / 379505 \mathrm{a} 0$

Cerveny, P.F., Naeser, CH.W., Kelemen, P.B., Lieberman, J.E. and Zeitler P.K.: 1989, Zircon fission-track ages from the Gasherbrum Diorite, Karakoram Range, northern Pakistan. Geology, 17, 1044-1048. DOI: 10.1130/0091-7613(1989)017<1044:ZFTAFT >2.3.CO;2

Cílek, V. and Kalvoda, J.: 1983, Weathering rinds of the Karakoram crystalline rocks. Časopis pro Mineralogii a Geologii, 28, No. 2, 127-137, 4 plates.

Coward, M.P., Jan, M.Q., Rex, D., Tarney, J., Thirlwall, M. and Windley, B.F.: 1982, Geotectonic framework of the Himalaya of N Pakistan. Journal of the Geological Society of London, 139, 299-308. DOI: $10.1144 /$ gsjgs.139.3.0299

Coward, M.P., Windley, B.F., Broughton, R.D., Luff, I.W., Petterson, M.G., Pudesy, C.J., Rex, D.C. and Khan, M.A.: 1986, Collision tectonics in the N.W. Himalayas. In: Coward, M.P. and Ries, A. (Eds.):
Collision tectonics. Geological Society of London Special Publications, 19, 203-219.

DOI: 10.1144/GSL.SP.1986.019.01.11

Coward, M.P., Butler, R.W.B., Khan, M.A. and Knipe, R.J.: 1987, The tectonic history of Kohistan and its implications for Himalayan structure. Journal of the Geological Society of London, 144, 377-391.

DOI: 10.1144/gsjgs.144.3.0377

Coward, M.P., Butler, R.W.H., Chambers, A.F., Graham, R.H., Izatt, C.N., Khan, M.A., Knipe, R.J., Prior, D.J., Treolar, P.J. and William, M.P.: 1988, Folding and imbrication of the Indian crust during Himalayan collision. Philosophical Transactions of the Royal Society of London, Series A, 326, 89-116.

Crawford, M.B.: 1988, Leucogranites of the NW Himalaya. $\mathrm{Ph} . \mathrm{D}$. Thesis. University of Leicester.

Debon, F., Le Fort, P., Shepard, S.M.F. and Sonet, J.: 1986, The Four Plutonic Belts of the TranshimalayaHimalaya: a chemical, mineralogical, isotopic, and chhronological synthesis along a Tibet-Nepal section. Journal of Petrology, 27, No. 11, 219-250.

DOI:10.1093/petrology/27.1.219

Derbyshire, E.: 1996, Quaternary glacial sediments, glaciation style, climate and uplift in the Karakoram and northwest Himalaya: review and speculations. Palaeogeography, Palaeoclimatology and Palaeoecology, 120, No. 1-2, 147-157.

Derbyshire, E., Fort, M. and Owen, L.: 2001, Geomorphological hazards along the Karakoram highway: Khunjerab pass to the Gilgit river, Northernmost Pakistan. Erdkunde, 55, No. 1, 49-71 and $40 \mathrm{pp}$. appendix. DOI: 10.3112/erdkunde.2001.01.04

Derbyshire, E., Li-Jijun, Perrott, F.A., Xu-Shuying and Watters, R.S.: 1984, Quaternary glacial history of the Hunza Valley, Karakoram mountains, Pakistan. In: Miller, K.J. (Ed.): The International Karakoram Project. Cambridge University Press, Cambridge, 2, 456-495.

Desio, A.: 1974, Karakorum mountains. In: Spencer, A.M. (Ed.): Mesozoic - Cenozoic Orogenic Belts: Data for Orogenic Studies; Alpine - Himalayan Orogens. The Geological Society of London, Special Publications, 4 , 255-266.

Desio, A.: 1979, Geological evolution of the Karakoram. In: Abul Farah and De Jong, K.A. (Eds.): Geodynamics of Pakistan. Quetta, 111-124.

Desio, A. and Martina, E.: 1972, Geology of the Upper Hunza Valley, Karakorum, West Pakistan. Bulletin of the Italian Geological Society, 91, 283-314.

Dunkl, I.: 2002, TRACKKEY: a Windows program for calculation and graphical presentation of fission track data. Computers \& Geosciences, 28, No. 1, 3-12. DOI: 10.1016/S0098-3004(01)00024-3

England, P. and Molnar, P.: 1990, Surface uplift, uplift of rocks, and exhumation of rocks. Geology, 18, 11731177.

DOI: 10.1130/0091-7613(1990)018«1173:SUUORA 2.3.CO;2

Fitzgerald, P.G. and Gleadow, A.J.W.: 1988, Fission-track geochronology, tectonics and structure of the Transantarctic Mountains in Northern Victoria Land, Antarctica. Chemical Geology, Isotope Geoscience Section, 73, 169-198.

DOI: 10.1016/0168-9622(88)9014-0

Fitzgerald, P.G. and Gleadow, A.J.W.: 1990, New approaches in fission track geochronology as a tectonic tool: Example from the Transantarctic 
Mountains. Nuclear Tracks, 17, 351-357.

DOI: $10.1016 / 1359-0189(90) 90057-5$

Fleischer, R.L., Price, P.B. and Walker, R.M.: 1965, Effects of temperature, pressure and ionisation on the formation and stability of fission tracks in minerals and glasses. Journal of Geophysical Research, 70, 1497-1502. DOI: 10.1029/JZ070i006p01497

Foster, D.A. and Gleadow, A.J.W.: 1992, The morphotectonic evolution of rift-margin mountains in central Kenya: Constrains from apatite-fission track thermochronology. Earth and Planetary Science Letters, 113, 157-171.

DOI: $10.1016 / 0012-821 X(92) 90217-J$

Foster, D.A., Gleadow, A.J.W. and Mortimer, G.: 1994, Rapid Pliocene exhumation in the Karakoram (Pakistan), revealed by fission-track thermochronology of the K2 gneiss. Geology, 22, No. 1, 19-22. DOI: 10.1130/0091-7613(1994)0222.3.CO;2

Gallagher, K., Brown, R. and Johnson, Ch.: 1998, Fission track analysis and its applications to geological problems. Annual Review of Earth and Planetary Sciences, 26, 519-572.

DOI: 10.1146/annurev.earth.26.1.519

Galbraith, R.F.: 1981, On statistical models for fission track counts. Mathematical Geology, 13, 471-488. DOI: $10.1007 / \mathrm{BF} 01034498$

Gardner, J.S. and Hewitt, K.: 1990, A surge of Bualtar Glacier, Karakoram Range, Pakistan: a possible landslide trigger. Journal of Glaciology, 36, No. 123, 159-162.

Goudie, A.S.: 1984, Salt efflorescences and salt weathering in the Hunza Valley, Karakoram mountains, Pakistan. In: Miller, K.J. (Ed.): The International Karakoram Project. Cambridge University Press, Cambridge, 2, 607-615.

Goudie, A.S., Brunsden, D., Collins, D.N., Derbyshire, E., Ferguson, R.I., Hashnet, Z., Jones, D.K.C., Perrott, F.A., Said, M., Waters, R.S. and Whalley, W.B.: 1984a, The geomorphology of the Hunza valley, Karakoram Mountains, Pakistan. In: Miller, K.J. (Ed.): The International Karakoram Project. Cambridge University Press, Cambridge, 2, 359-411.

Goudie, A.S., Jones, D.K.C. and Brunsden, D.: 1984b, Recent fluctuations in some glaciers of the western Karakoram mountains, Hunza, Pakistan. In: Miller, K.J. (Ed.): The International Karakoram Project. Cambridge University Press, Cambridge, 2, 411-455.

Goudie, A.S. and Kalvoda, J.: 2004, Recent geomorphological processes in the Nagar region, Hunza Karakoram. Acta Universitatis Carolinae, Geographica, XXXIX, 1, 135-148.

Green, P.F.: 1981, 'Track-in track' length measurements in annealed apatites. Nuclear Tracks, 5, 121-128. DOI: $10.1016 / 0191-278 X(81) 90034-2$

Green, P.F. and Durrani, S.A.: 1977, Annealing studies of tracks in crystals. Nuclear Track Detection, 1, 33-39. DOI: 10.1016/0145-224X(77)90021-7

Green, P.F., Duddy, I.R., Laslett, G.M., Hegarty, K.A., Gleadow, A.J.W. and Lovering, J.F.: 1989, Thermal annealing of fission tracks in apatite 4. Quantitative modelling techniques and extension to geological time scales. Chemical Geology, Isotope Geoscience Section, 79, 155-182.

DOI: 10.1016/0168-9622(87)90057-1

Hewitt, K.: 1989, The altitudinal organisation of Karakoram geomorphic processes and depositional environments.
In: Derbyshire, E. and Owen, L.A. (Eds.): Quaternary of the Karakoram and Himalaya. Zeitschrift für Geomorphologie, Supplementband, 76, 9-32.

Hewitt, K.: 2005, The Karakoram Anomaly? Glacier Expansion and the 'Elevation Effect,' Karakoram Himalaya. Mountain Research and Development, 25, No. 4, 332-340.

DOI: 10.1659/0276-4741(2005)025[0332:TKAGEA]2.0:CO;2

Hewitt, K.: 2009, Rock avalanches that travel onto glaciers and related developments, Karakoram Himalaya, Inner Asia. Geomorphology, 103, No. 1, 66-79.

DOI: 10.1016/j.geomorph.2007.10.017

Hewitt, K., Gosse, J. and Clague J. J.: 2011, Rock avalanches and the pace of late Quaternary development of river valleys in the Karakoram Himalaya. GSA Bulletin, 123, No. 9-10, 1836-1850. DOI: 10.1130/B30341.1

Honegger, K., Dietrich, V., Frank, W., Gansser, A., Thoni, M. and Trommsdorff, V.: 1982, Magmatism and metamorphism in the Ladakh Himalayas, the IndusTsangpo Suture Zone. Earth and Planetary Science Letters, 60, 253-292. DOI: $10.1016 / 0012-821 X(82) 90007-3$

Hurford, A.J. and Green, P.F.: 1983, The zeta age calibration of fission-track dating. Chemical Geology, 41, 285-317. DOI:10.1016/S0009-2541(83) 80026-6

Iturrizaga, L.: 2001, Lateroglacial valleys and landforms in the Karakoram Mountains (Pakistan). In: Kuhle, M. (Ed.): Glaciogeomorphology and Prehistoric Glaciation in the Karakorum and Himalaya. GeoJournal, 55 and 56, No. 1-4, 397-428.

Jonckheere, R. and Van den Haute, P.: 2002, On the efficiency of fission-track counts in an internal and external apatite surface and in a muscovite external detector. Radiation Measurements, 35, 29-40. DOI: $10.1016 / \mathrm{S} 1350-4487(01) 00262-1$

Kalvoda, J.: 1984, The nature of geomorphic processes in the Himalayas and Karakoram. Studia

Geomorphologica Carpatho-Balcanica, 18, 45-64.

Kalvoda, J.: 1990, Geomorphology of the Gharesa glacier region in the Karakoram. Acta Universitatis Carolinae, Geographica, XXV, No. 2, 3-27.

Kalvoda, J.: 1992a, Geomorphological record of the Quaternary Orogeny in the Himalaya and the Karakoram. In: Development in Earth Surface Processes, 3, Elsevier, Amsterdam, 315 pp.

Kalvoda, J.: 1992b, Some observations of the morphotectonic activity in the Pamírs and Tian-Shan. Acta Universitatis Carolinae, Geographica, XXVII, No. 2, 3-20.

Kalvoda, J. and Goudie, A.S.: 2007, Landform evolution in the Nagar region, Hunza Karakoram. In: Goudie, A.S. and Kalvoda, J. (Eds.): Geomorphological variations. P3K Publishers, Prague, 87-126.

Kalvoda, J., Košler, J. and Svojtka, M.: 2004, Morphotectonic evidence for chronodynamics of uplift in the East Nepal Himalaya. Acta Universitatis Carolinae, Geographica, XXXIX, No. 1, 149-162.

Kalvoda, J. and Rosenfeld, Ch. (Eds.): 1998, Geomorphological Hazards in High Mountain Areas. The GeoJournal Library, 46, Kluwer Academic Publishers, Dordrecht, 314 pp.

Ketcham, R.A.: 2005, Forward and inverse modelling of low-temperature thermochronometry data. In: Reiners P.W. and Ehlers T.A. (Eds.): Low-Temperature Thermochronology: Techniques, Interpretations, and Applications. Reviews of Mineralogy and 
Geochemistry, 58, 275-314.

DOI: $10.2138 / \mathrm{rmg} .2005 .58 .11$

Ketcham, R.A., Carter, A., Donelick, R.A., Barbarand, J. and Hurford, A.J.: 2007a, Improved measurement of fission-track annealing in apatite using c-axis projection. American Mineralogist, 92, No. 5-6, 799810. DOI: $10.2138 / \mathrm{am} .2007 .2281$

Ketcham, R.A. and Apatite to Zircon, Inc.: 2007b, HeFTy software version 1.4.

Kuhle, M.: 1988a, Zur Geomorphologie der nivalen und subnivalen Höhenstufe in der Karakoram-NAbdachung zwischen Shaksgan-Tal und K2 Nordsporn: Die quartäre Vergletscherung und ihre geoökologische Konsequenz. In: Becker, H. (Ed.): Tagungsberichte des Wissenschaftlichen Abhandlungen, 46. Deutschen Geographentages (München), 413-419.

Kuhle, M.: 1988b, Letzteiszeitliche Gletscherausdehnung vom NW-Karakoram bis zum Nanga Parbat (HunzaGilgit- und Indusgletschersystem). In: Becker, H. (Ed.): Tagungsberichte des Wissenschaftlichen Abhandlungen, 46. Deutschen Geographentages (München), 420-424.

Kuhle, M.: 2001, The maximum Ice Age (LGM) glaciation of the Central- and South Karakoram: an investigation of the heights of its glacier levels and ice thickness as well as lowest prehistoric ice margin positions in the Hindukush, Himalaya and in East-Tibet on the Minya Konka-massif. In: Kuhle, M. (Ed.): Glaciogeomorphology and Prehistoric Glaciation in the Karakorum and Himalaya. GeoJournal, 55-56, No. 14, 397-428.

Kuhle, M.: 2001, The Past Hunza Glacier in Connection with a Pleistocene Karakorum Ice Stream Network during the Last Ice Age (Würm). In: Kreutzmann, H., Saijid, A. (Eds.): Karakoram in Transition. Oxford University Press, Karachi, 24-48.

Le Fort, P., Michard, A., Sonet, J. and Zimmerman, J.L.: 1983, Petrography, geochemistry, and geochronology of some samples from the Karakoram axial batholith (northern Pakistan). In: Shams, F.A. (Ed.): Granites of the Himalayas, Karakoram and Hindu Kush. Punjab University Institute of Geology, Lahore, Pakistan, 377-387.

Li Jijun, Derbyshire, E. and Shuying, X.: 1984, Glacial and paraglacial sediments of the Hunza Valley, NorthWest Karakoram, Pakistan: a preliminary analysis. In: Miller, K.J. (Ed.): The International Karakoram Project, Cambridge University Press, Cambridge, 496-535.

Lisker, F., Ventura, B. and Glasmacher, U.A. (Eds.): 2009, Thermochronological Methods: from Palaeotemperature Constrains to Landscape Evolution Models. Geological Society of London, Special Publications, 324, 1-23. DOI: $10.1144 /$ SP324.0

Miller, J.A., Horsfall, J.A.C., Petford, N. and Tizard, R.H.: 1993, Counting fission tracks in mica external detectors. Pure and Applied Geophysics, 140, No. 4, 667-680. DOI: 10.1007/BF00876583

Murakami, M. and Svojtka, M.: 2007, Zircon fission-track technique: a laboratory procedure adopted at the Institute of Geology, Academy of Sciences of the Czech Republic. Fission Track News Letters, 20, 13-19.

Naeser, C.W.: 1979, Fission-track dating and geological annealing of fission tracks. In: Jäger, E. and Hunziker, J.C. (Eds.): Lectures in Isotope Geology. Springer New York, 154-169.
Owen, L.A. and Derbyshire, E.: 1989, The Karakoram glacial depositional system. In: Derbyshire, E., Owen, L.A. (Eds.): Quaternary of the Karakoram and Himalaya. Zeitschrift für Geomorphologie, Supplementband, 76, 33-73.

Owen, L.A. and Derbyshire, E.: 1993, Quaternary and Holocene intermontane basin sedimentation in the Karakoram Mountains. In: Shroder, J.F. (Ed.): Himalaya to the Sea. Routledge, London, 108-131.

Owen, L.A., Finkel, R.C., Caffee, M.W. and Gualtieri, L.: 2002, Timing of multiple late Quaternary glaciations in the Hunza Valley, Karakoram Mountains, northern Pakistan: Defined by cosmogenic radionuclide dating of moraines. Bulletin of the Geological Society of America, 114, 5, 593-604. DOI: 10.1130/0016-7606(2002)114«0593:TOMLQG 2.0.CO;2

Paffen, K.H., Pillewitzer, W. and Schneider, H.J.: 1956, Forschungen im Hunza-Karakoram. Erdkunde, 10, No. 1, 1-33.

Pudsey, C.J., Coward, M.P., Luff, I.W., Shackelton, R.M., Windley, B.F. and Jan, M.Q.: 1985, Collision zone between the Kohistan arc and the Asian plate in NW Pakistan. Transactions of the Royal Society of Edinburgh, Earth Sciences, 76, 463-479. DOI: $10.1017 / \mathrm{S} 026359330001066 \mathrm{X}$

Rex, A.J., Searle, M.P., Tirrul, R., Crawford, M.B., Prior, D.J., Rex, D.C. and Bertrand, J.M.: 1988, The geochemical and tectonic evolution of the Central Karakoram, North Pakistan [and discussion]. Philosophical Transactions of the Royal Society of London, Series A, Mathematical and Physical Sciences, 326 (1589), 229-255.

Ring, U., Brandon, M.T., Willett, S.D. and Lister, G.S.: 1999, Exhumation processes. In: Ring, U., Brandon, M.T. Willett, S.D. and Lister, G.S. (Eds.): Exhumation processes: Normal Faulting, Ductile Flow, and Erosion. Geological Society, London, Special Publications, 154, 1-27. DOI: 10.1144/GSL.SP.1999.154.01.01

Rolland, Y., Pecher, A. and Picard, C.: 2000, Middle Cretaceous back-arc formation and arc evolution along the Asian margin: the Shyok Suture Zone in northern Ladakh (NW Himalaya), Tectonophysics, 325, No. 1, 145-173.

DOI: 10.1016/S0040-1951(00)00135-9

Sachani, H.K., Mukherjee, B.K., Ogasawara, Y., Maruyama, S., Ishida, H., Muko, A. and Yoshioka, N.: 2004, Discovery of coesite from Indus suture zone (ISZ), Ladakh, India: Evidence for deep subduction. European Journal of Mineralogy, 16, No. 2, 235-240. DOI: $10.1127 / 0935-1221 / 2004 / 0016-0235$

Scharer, U., Xu, R.H. and Allegre, C.J.: 1984, U-Pb geochronology of Gandase, Transhimalaya. Plutonism in the Lahasa- Xigaze region, Tibet. Earth and Planetary Science Letters, 69, 311-320. DOI: $10.1016 / 0012-821 X(84) 90190-0$

Searle, M.P.: 1986, Structural evolution and sequence of thrusting in the High Himalayan, Tibetan-Tethys and Indus suture zones of Zanskar and Ladakh, Western Himalaya. Journal of Structural Geology, 8, No. 8, 923-936. DOI: 10.1016/0191-8141(86)90037-4

Searle, M. P.: 1991, Geology and tectonics of the Karakoram Mountains. Wiley, London, 358 pp.

Searle, M. P.: 2007, Diagnostic features and processes in the construction and evolution of Oman-, Zagros-, Himalayan-, Karakoram-, and Tibetan-type orogenic belts. Geological Society of America Memoirs, 200, 41-61. DOI: 10.1130/2007.1200(04) 
Searle, M.P., Winley, B.F., Coward, M.P., Cooper, D.J.F., Rex, A.J., Rex, D., Tingdong Li, Xuchung Xiao, Jan, M.Q., Thakur, V.C. and Kumar, S.: 1987, The closing of Tethys and the tectonics of the Himalaya. Geological Society of America Bulletin, 98, 678-701. DOI: 10.1130/0016-7606(1987)98<678:TCOTAT $2.0 . C O ; 2$

Searle, M.P., Cooper, D.J.W., Rex, A.J. and Herren, E.: 1988, Collision Tectonics of the Ladakh-Zanskar Himalaya. Philosophical Transactions of the Royal Society of London, Serie A, 326, 117-150.

Searle, M.P., Rex, A.J., Tirrul, R., Barnicoat, A. and Windley, B.F.: 1989, Metamorphic, magmatic, and tectonic evolution of the central Karakoram in the Biafo-Baltoro-Hushe regions of northern Pakistan. In: Malinconico, L.L. and Lillie, R.J. (Eds.): Tectonics of the western Himalayas. Geological Society of America Special Papers, 232, 47-73.

DOI: 10.1130/SPE232-p47

Searle, M.P. and Tirrul, R.: 1991, Structural and thermal evolution of the Karakorum crust. Journal of the Geological Society of London, 148, 65-82. DOI: $10.1144 /$ gsjgs.148.1.0065

Seong, Y.B., Owen, A., Bishop, M.P., Bush, A., Clendon, P., Copland, L., Finkel, R.C., Kamp, U. and Shroeder, J.F., Jr.: 2007, Quaternary glacial history of the central Karakoram. Quaternary Science Reviews, 26, 3384-3405.

DOI: 10.1016/j.quascirew.2007.09.015

Seong, Y.B., Bishop, M.P., Bush, A., Clendon, P., Copland, L., Finkel, R.C., Kamp, U., Owen, L.A. and Shroeder, J.F., Jr.: 2009, Landforms and landscape evolution in the Skardu, Shigar, and Braldu valleys, central Karakoram. Geomorphology, 103, 251-267. DOI: 10.1016/j.geomorph.2008.04.026

Shroder, J.F. and Bishop, M.P.: 2000, Unroofing of the Nanga Parbat Himalaya. In: Khan, M.A., Treolar, P.J., Searle, M.P. and Qasim, J.M. (Eds.): Tectonics of the Nanga Parbat syntaxis and the western Himalaya. The Geological Society of London Special Publications, $170,163-179$.

DOI: 10.1144/GSL.SP.2000.170.01.09

Schneider, H.J.: 1957, Tektonik und Magmatismus in NWKarakorum. Geologische Rundschau, 46, 426-476. DOI: $10.1007 / \mathrm{BF} 01803034$
Schneider, H.J.: 1960, Geosynklinale Entwicklung des Magmatismus an der Wende PalāozoikumMesozoikum im NW-Himalaya and Karakorum. Geologische Rundschau, 50, 334-352. DOI: $10.1007 / \mathrm{BF} 01786850$

Singh, S. and Jain, A.K.: 2003, Himalayan Granitoids. In: Singh, S. (Ed.): Granitoids of the Himalayan Collisional Belt. Journal of the Virtual Explorer, Electronic Edition. 11, Paper 01.

Summerfield, M.A.: 1991, Global geomorphology: an introduction to the study of landforms. Longman, Harlow, $537 \mathrm{pp}$.

Tagami, T. and O'Sullivan, P.B.: 2005, Fundamentals of fission-track thermochronology. Reviews of Mineralogy and Geochemistry, 58, 19-47. DOI: $10.2138 / \mathrm{rmg} .2005 .58 .2$

Tahirkheli, R.K.: 1982, Geology of the Himalaya, Karakoram and Hindukush in Pakistan. Geological Bulletin, University of Peshawar, 15, No. 1, 1-51.

Thiede, R.C. and Ehlers, T.A.: 2013, Large spatial and temporal variations in Himalayan denudation. Earth and Planetary Science Letters, 371, 278-293. DOI: $10.1016 /$ j.eps1.2013.03.004

Wagner, G.A., Reimer, G.M. and Jager, E.: 1977, Cooling ages derived by apatite fission track, mica $\mathrm{Rb}-\mathrm{Sr}$ and $\mathrm{K}-\mathrm{Ar}$ dating: The uplift and cooling history of the central Alps. Memorie Istituti Geologia e mineralogia dell Universita di Padova, 30, 1-28.

Wagner, G.A. and Van Den Haute, P.: 1992, Fission-Track Dating. Solid Earth Sciences Library, Kluwer Academic Publishers, Dordrecht, 285 pp.

Weinberg, R.F. and Dunlap, W.J.: 2000, Growth and deformation of the Ladakh Batholith, northwest Himalayas: implications for timing of continental collision and origin of calc-alkaline batholith. Journal of Geology, 108, 303-320. DOI: 10.1086/314405

Wiche, K.: 1959, Klimamorphologische Untersuchungen im westlichen Karakorum. Verhandlungen des deutschen Geographentages, 32, 190-203.

Wiche, K.: 1962, Le periglaciaire dans la Karakorum de 1' Ouest. Biuletyn Periglacialny, 11, 103-110. 


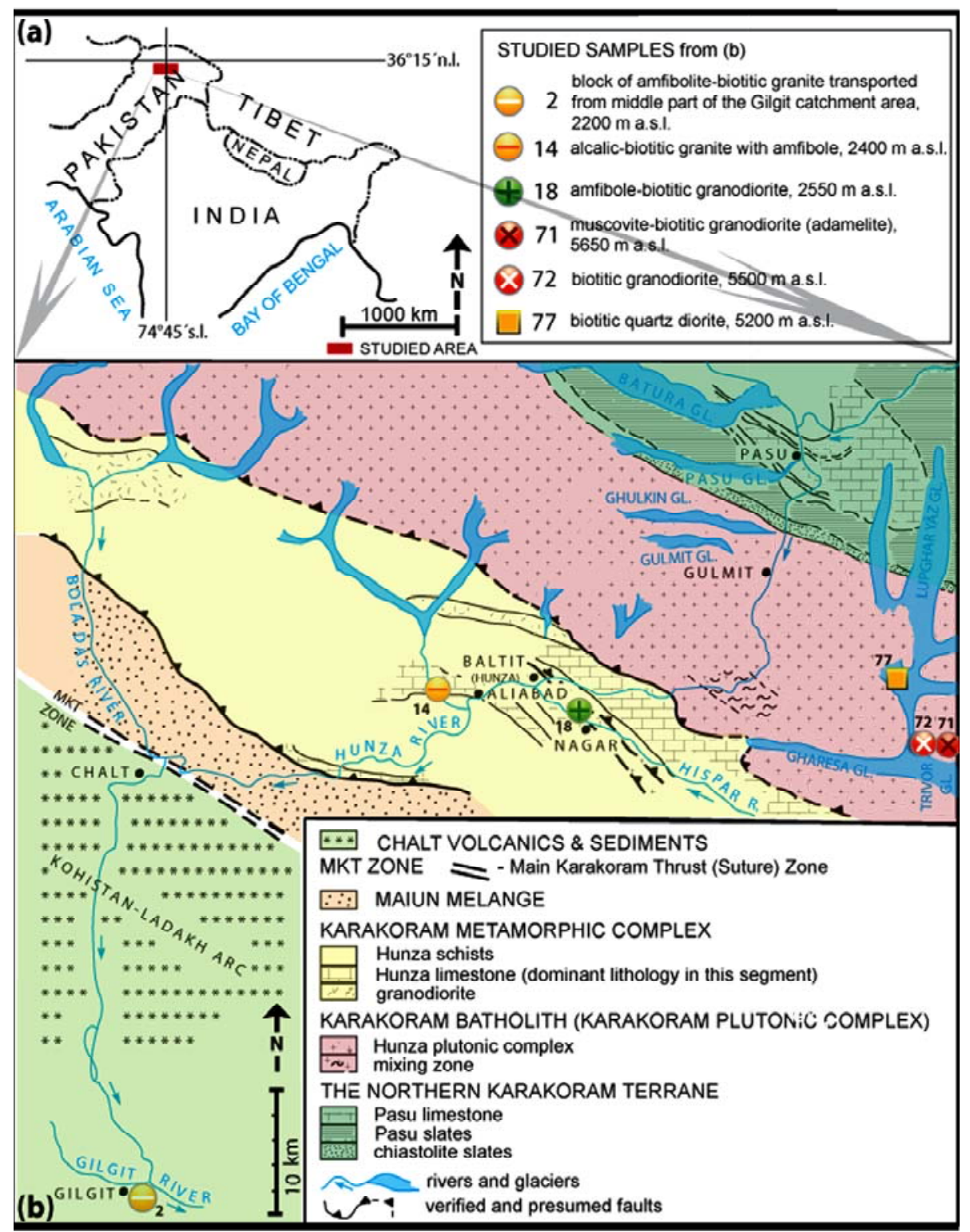

Fig. 1 Geographical position (a) and schematic geological map (b) of the studied area in the Hunza Karakoram. Description of the rock samples is in the text of chapter 4 .

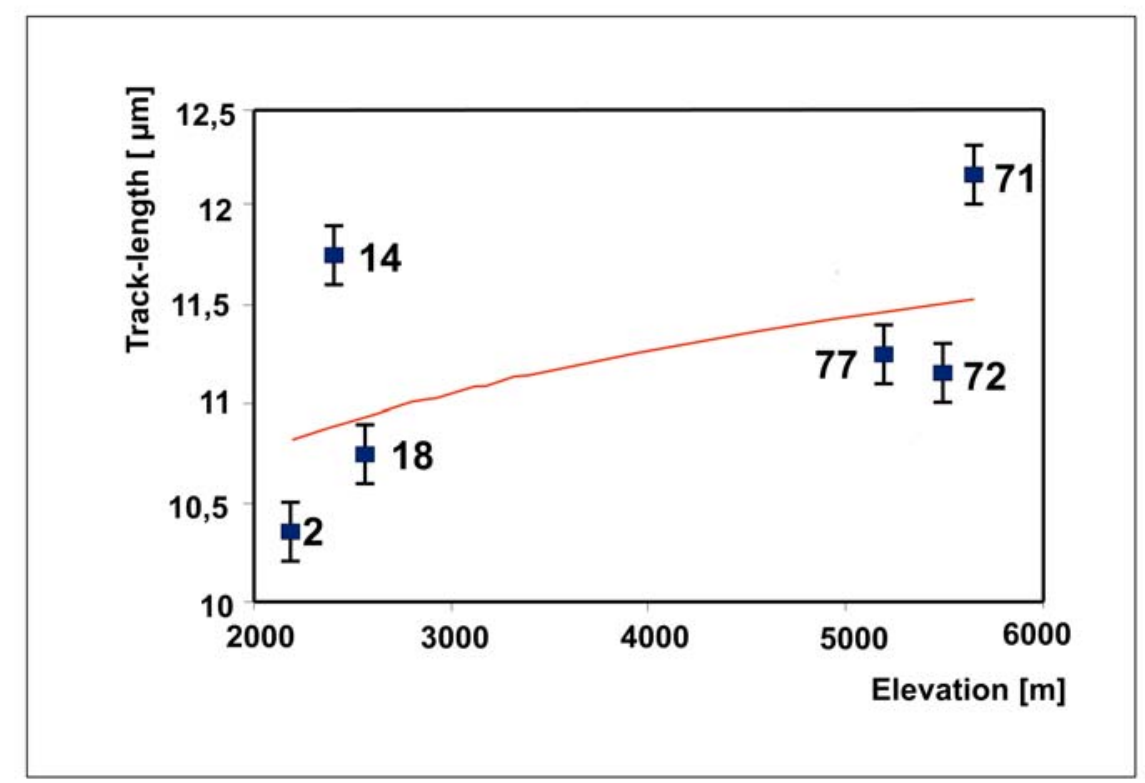

Fig. 8 Track-length vs. topographical elevation of the studied samples. The red line shows a slightly increasing trend in average lengths of measured confined tracks with increasing elevation. 

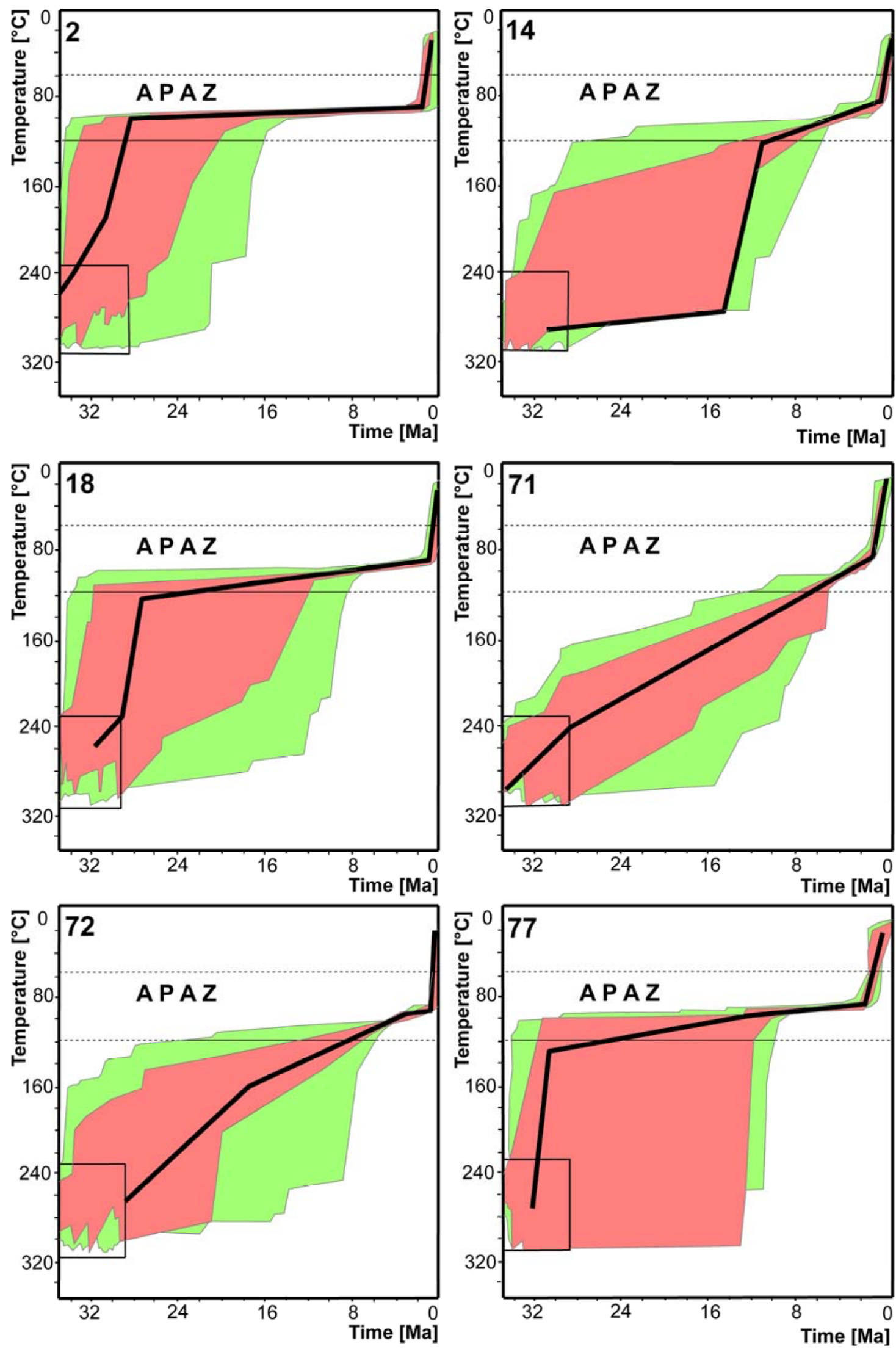

Fig. 6 Results of thermal modelling of apatite fission-track data. Using the approach of Ketcham et al. (2005, 2007a, b) "best-fit" time-temperature (T-t) diagrams were generated by HeFTy modelling program. Geological constraints following ages and temperature are taken from zircon fission-track dating from $\mathrm{K} 2$ gneiss $\left(310-230^{\circ} \mathrm{C} / 32 \pm\right.$ 6 Ma) by Foster et al. (1994).

Notes: the results of thermal modelling of apatite fission-track data are displayed as colour-different envelopes and thick black lines and indicate three reliability levels. Red envelopes indicate all T-t paths with a probability value of at least 0.5 ; green envelopes are for all $\mathrm{T}$-t paths with a probability value of at least 0.05 and the thick black lines are the best fits. APAZ = the apatite partial annealing zone. 

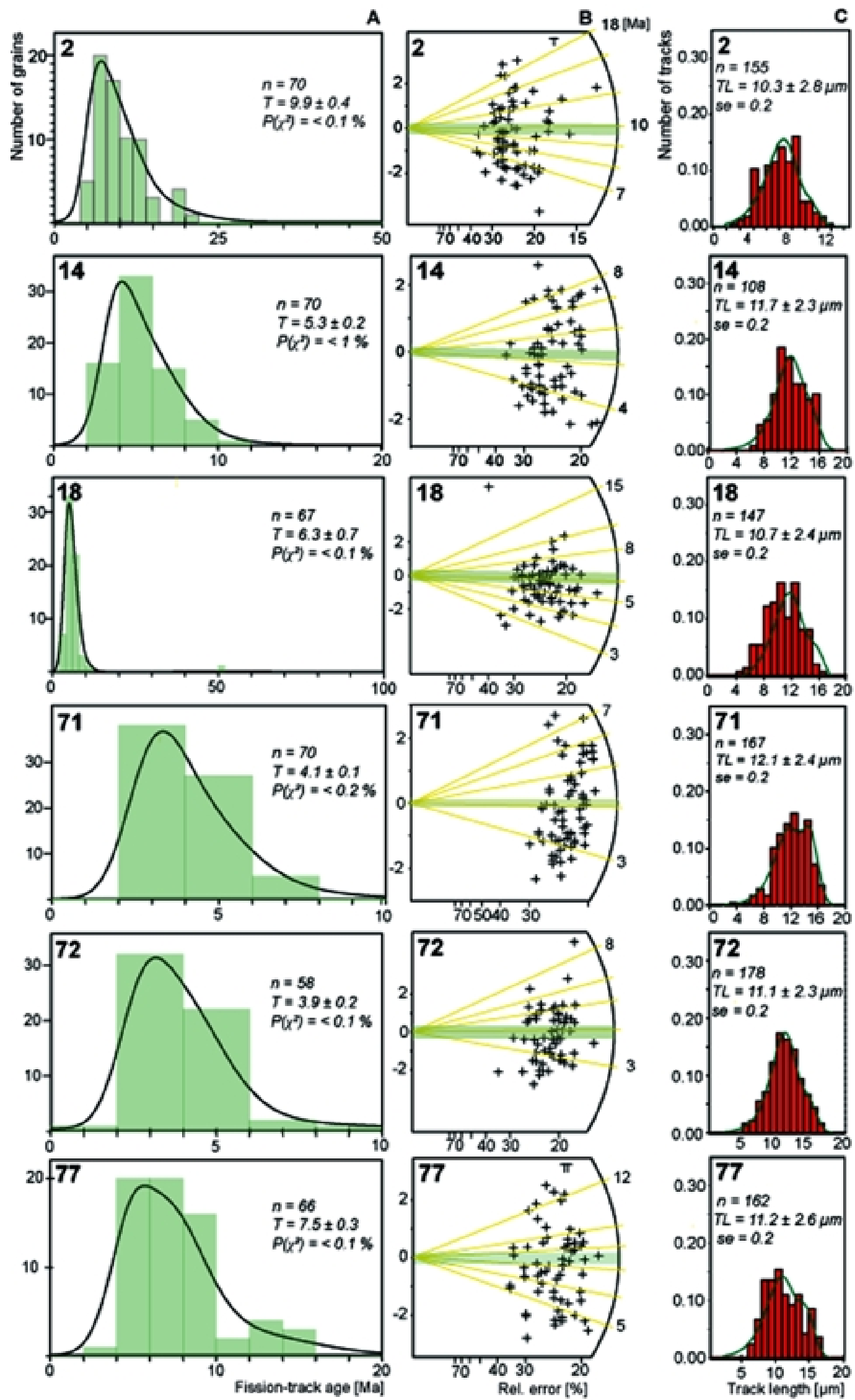

Fig. 7 Apatite fission-track age data from the Hunza Karakoram. (A) - Age spectrum plot: $\mathrm{n}$ - number of counted grains in studied sample; $\mathrm{T}$ - apatite fission-track mean age with 1 sigma error; $\mathrm{P}\left(\chi^{2}\right)$ - statistical probability test; (B) - Radial plots displaying AFT-single grain ages of samples that failed the $\mathrm{P}\left(\chi^{2}\right)$-test; the green zone in the radial plot represents the mean age of samples; (C) - The track-length-frequency histograms: $n$ - number of counted confined tracks in the studied sample; TL - average confined track lengths $[\mu \mathrm{m}]$; se - standard error. 